\title{
Desain Kemasan Tradisional Dalam Konteks Kekinian
}

\author{
Benny Rahmawan Noviadji
}

Staff Pengajar Program Studi Desain Komunikasi Visual, Fakultas Seni, Institut Informatika Indonesia (IKADO) Surabaya

Email : benz.rahmawan@gmail.com

Abstract - The diversity of traditional food is a part of the Indonesian nation's wealth. Along with the development of technology and lifestyle, traditional food packaging community naturally becoming obsolete due to packaging impressed judged to be synonymous with cheap and dirty, unhygienic and impractical . Then slowly replaced with materials such as plastic, cans and Styrofoam are prone to pollute the environment. Several types of traditional packaging using natural ingredients. But it is not designed as a serious and still serves as a container or wrapper only, not so into consideration in terms of increased sales, image enhancement, local identity, not even thought about issues such as environmentally friendly recycle, reduce, and reuse . The role of the designer is to maintain the existence of the traditional packaging that still exist and more appreciated by giving traditional packaging solutions in creating more dynamic in terms of several aspects when faced with the current conditions, among others, in terms of novelty designs that are more innovative and unique selling points high given the increasing number of products on the market. A touch of unique design will be able to make traditional packaging into an exclusive packaging. Traditional packaging was also created to be able to maintain the characteristic of local culture without ignoring local identity to represent the local culture. More important consideration also needs to pay attention to in terms of eco-friendly, considering the waste problem is now starting to bloom voiced, so it should be easy to traditional packaging for recycling. Present context is intended to things above solving traditional packaging design solutions to some of the conditions existing problems.

Keyword :Traditional Packaging, Innovative Design

\section{PENDAHULUAN}

Indonesia terdiri dari keragaman suku bangsa sehingga memiliki keragaman budaya. Budaya tersebut mencakup sistem teknologi tradisional, adat istiadat, dan sebagainya. Di antara keragaman itu, salah satu hasil budaya yang menarik adalah keragaman jenis makanan tradisional, keterkaitan erat yang ada di dalamnya antara lain teknologi pengolahan bahan dalam proses pembuatan kemasan maupun proses memasak makanan tradisional. Seluruh suku di Indonesia memiliki kekhasan dalam jenis, teknologi, dan kemasan makanan tradisional. Keberadaan makanan tradisional itu pada umumnya tidak terlepas dari adat istiadat suatu masyarakat tertentu. Sehingga 
makanan tradisional dapat menjadi cerminan budaya suatu masyarakat.

Budaya kemasan sebenarnya telah dimulai sejak manusia mengenal sistem penyimpanan bahan makanan. Sistem penyimpanan bahan makanan secara tradisional diawali dengan memasukkan bahan makanan ke dalam suatu wadah yang ditemuinya. Pada awalnya kemasan masih terkesan seadanya dan lebih berfungsi untuk melindungi makanan/barang terhadap pengaruh cuaca atau proses alam lainnya yang dapat merusaknya. Selain itu, kemasan juga berfungsi sebagai wadah agar barang mudah dibawa selama dalam perjalanan. Seiring dengan perkembangan jaman yang semakin kompleks, barulah terjadi penambahan nilai-nilai fungsional dan peranan kemasan dalam pemasaran mulai diakui sebagai satu kekuatan utama dalam persaingan pasar.

Bahan kemasan alami ditinjau dari segi keberadaannya, masih banyak terdapat di daerah-daerah di Indonesia dengan harga yang relatif murah, lagi pula tidak memberikan dampak yang negatif terhadap pencemaran lingkungan (ramah lingkungan), malah sebaliknya bahan kemasan ini dapat terurai oleh bakteri secara alamiah. Akan tetapi bilamana tidak segera ditangani, maka limbah bahan kemas alami ini dapat pula memberikan dampak negatif yaitu menimbulkan pencemaran, aroma yang dihasilkan dari proses penguraian tersebut dapat menghasilkan bau yang tidak sedap.

Berbagai kemasan tradisional yang masih banyak digunakan antara lain bambu, kayu, dedaunan dan sebagainya. Penggunaan daun sebagai bahan kemasan tradisional sudah lazim dipakai di seluruh masyarakat Indonesia, selain murah dan praktis cara pemakaiannya, daun ini juga masih mudah didapat, akan tetapi kemasan daun ini bukan merupakan kemasan yang bersifat representatif, sehingga pada saat penanganannya harus ekstra hati-hati.

Seiring dengan perkembangan teknologi dan gaya hidup, kemasan tradisional makanan alami tersebut mulai ditinggalkan masyarakat karena dinilai menjadi kemasan yang terkesan murahan dan diidentikan dengan kumuh, tidak higienis, tidak praktis. Kemudian perlahan berganti dengan pembungkus/wadah buatan manusia yang kini biasa kita gunakan seperti kertas, plastik, kaleng dan Styrofoam. Selama ini, wadah dan pembungkus makanan buatan yang modern itu memang menciptakan kesan modern, praktis, simple dan bersih. Namun material seperti ini sulit didaur ulang, hingga rentan mencemari lingkungan. Fungsi kantung plastik sebetulnya hanya untuk membawa produk dari pasar ke rumah. Setibanya di rumah, yang dinikmati adalah isinya, sementara plastik masuk ke keranjang sampah. Jadi tanpa disadari, sebetulnya makanan yang dibungkus aluminium kemudian dilapisi lagi dengan plastik (misal: kemasan snack, coklat, dll), telah menciptakan limbah yang berlapis-lapis.

Pada era sekarang, isu-isu tentang lingkungan mulai marak disuarakan. Salah satunya masalah sampah yang menjadi perhatian banyak orang termasuk pemerintah. Sampah anorganik khususnya, yang butuh puluhan tahun bahkan ratusan tahun untuk dapat didegradasi oleh 
lingkungan menjadi masalah kompleks. Dalam satu sisi, penggunaan bahan pengemas yang umumnya anorganik tidak dapat dilepaskan karena konsumen menghendaki kepraktisan yang bisa didapatkan dengan penggunaan pengemas anorganik tersebut. Sementara penggunaan pengemas anorganik maka limbahnya akan mencemari lingkungan. Berdasarkan uraian di atas, maka penulis mengangkat tema kemasan tradisional sebagai kemasan yang berpotensi untuk dikembangkan dan dipasarkan secara luas dengan sentuhan kebaruan atas berbagai inovasi-inovasi kreatif sebagai solusi untuk mempertahankan keberadaannya agar makin lebih dihargai, memiliki nilai jual yang tinggi serta ramah lingkungan.

\section{MAKANAN TRADISIONAL}

Kegiatan makan seringkali dianggap sebagai kegiatan pemenuhan kebutuhan dasar semata. Padahal dari sudut kajian antropologi budaya, kegiatan makan merupakan suatu bagian dari tujuh unsur kebudayaan. Setiap kebudayaan memiliki kekhasan tersendiri dalam kegiatan makan, mulai dari menyiapkan bahan makanan, proses memasak, mengemas, hingga proses memakannya.

Makanan tradisional adalah makanan yang telah membudaya di kalangan masyarakat Indonesia, serta telah ada sejak nenek moyang suku nusantara. Menurut Winarno (1993), makanan tradisional adalah makanan yang pekat dengan tradisi setempat. Pangan tradisional sebagai makanan yang dikonsumsi oleh golongaan etnik dan wilayah spesifik, diolah berdasarkan resep yang secara turun temurun. Bahan yang digunakan berasal dari daerah setempat dan makanan yang dihasilkan juga sesuai dengan selera masyarakat. Makanan tradisional merupakan makanan yang memiliki ciri khas yang tidak ditemukan di wilayah lain.

Fenomena Usaha Kecil dan Mikro (UKM) yang banyak mengundang pendapat dan perhatian pemerintah karena peran UKM sebagai tulang punggung ekonomi dari Negara-negara berkembang seperti Indonesia. Sumbangan untuk sektor ini merupakan lahan kerja dan sumber penghasilan bagi mayoritas penduduknya. Menurut Federasi Pengemasan Indonesia pada Indonesian Packaging Directory 20042005 menyatakan bahwa angka statistik yang diterbitkan oleh kementerian Koperasi dan UKM (2002) menunjukkan sekitar 41 juta unit UKM yang mempekerjakan sekitar 68 juta tenaga kerja dan menyumbang $40 \%$ dari Produk Domestik Kotor (GDP) (Indonesian Packaging Directory 2004-2005; 20). Yang menarik sejak krisis ekonomi melanda Indonesia pada Tahun 1997, keberadaan UKM ini akan semakin signifikan dan cukup berperan dalam meningkatkan pertumbuhan ekonomi dibandingkan dengan sektor korporasi.

Keanekaragaman jenis makanan tradisional merupakan bagian dari kekayaan bangsa Indonesia. Namun, keberadaannya terancam pangan modern produksi massal industri besar. Pangan tradisional semakin tertekan globalisasi perdagangan dunia, termasuk rencana ASEAN Economic Community (AEC) pada 2015. Produk yang banyak diusahakan usaha mikro kecil dan menengah ini masih minim sentuhan inovasi. Banyak kemasan 
tradisional terkesan asal-asalan, sehingga kurang menarik minat konsumen.

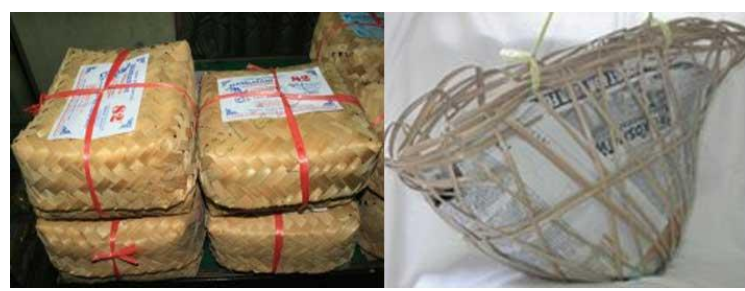

Gambar 1. Contoh Kemasan yang masih minim sentuhan inovasi

Di Yogyakarta maupun di daerah lain seperti Bandung masih banyak sekali produk makanan khas yang tidak dikemas secara spesifik menunjukkan kekhasan kota masing-masing, seperti: Bakpia Pathuk masih tetap dikemas dengan menggunakan kotak kardus, yang sebenarnya tidak jauh beda dengan Molen Bandung yang juga dikemas dengan menggunakan kotak kardus. Dalam hal ini belum ada perbedaan yang membedakan ciri khas kedaerahan antara Bakpia Pathuk dengan Molen Bandung. Tujuan pengemasan seharusnya tidak hanya untuk faktor keamanan produk maupun sebagai wadah atau sarana melindungi produk saja, namun produk yang dikemas, misalnya makanan khas tentunya kemasan tersebut mampu untuk mencirikan suatu daerah tertentu. Dalam hal ini fungsi kemasan sebagai identitas yang mutlak diperhatikan. Bagaimanapun kekhasan kemasan tradisional belum mampu tergantikan. Hal ini terbukti dengan derasnya serangan kemasan modern pada makanan tertentu, masih banyak yang bertahan menggunakan bahan baku alam sebagai kemasan hingga sekarang. Misalnya lumpia Semarang, batagor Bandung dan wingko babat yang kotaknya masih berupa besek. Bahkan ada juga jajanan pasar yang masih berbalut daun sebagai kemasannya.

\section{KEMASAN}

Kemasan berasal dari kata kemas yang berarti teratur (terbungkus) rapi dan bersih. Pengertian kemasan lainnya merupakan hasil mengemas atau bungkus pelindung dagang (niaga). Kemasan adalah wadah atau pembungkus, bagi produk pangan, kemasan mempunyai peranan penting dalam upaya mempertahankan mutu dan keamanan pangan serta meningkatkan daya tarik produk. Agar bahan pangan yang akan dikonsumsi bisa sampai kepada yang membutuhkannya dengan baik dan menarik, maka diperlukan pengemasan yang tepat. Pengemasan dalam hal ini ditunjukan untuk melindungi bahan pangan segar maupun bahan pangan olahan dari penyebab kerusakan, baik fisik, kimia, maupun mekanis.

Pada zaman modern seperti saat ini desain kemasan yang dipergunakan produsen bahan pangan diklasifikasikan dalam beberapa kelompok. Menurut Julianti dan Nurminah (2006), Kemasan dapat diklasifikasikan berdasarkan beberapa hal atau beberapa cara yaitu sebagai berikut :

1. Klasifikasi kemasan berdasarkan frekwensi pemakaian :

a) Kemasan sekali pakai (disposable), yaitu kemasan yang langsung dibuang setelah dipakai, seperti kemasan produk instant, permen, dll

b) Kemasan yang dapat dipakai berulangkali (multitrip) dan biasanya dikembalikan ke produsen, contoh : botol minuman, botol kecap, botol sirup. 
c) Kemasan atau wadah yang tidak dibuang atau dikembalikan oleh konsumen (semi disposable), tapi digunakan untuk kepentingan lain oleh konsumen, misalnya botol untuk tempat air minum dirumah, kaleng susu untuk tempat gula, kaleng biskuit untuk tempat kerupuk, wadah jam untuk merica dan lain-lain.

2. Klasifikasi kemasan berdasarkan struktur sistem kemas (kontak produk dengan kemasan):

a) Kemasan primer, yaitu kemasan yang langsung bersentuhan dengan produk yang di bungkusnya.

b) Kemasan sekunder, yang tidak bersentuhan langsung dengan produknya akan tetapi membungkus produk yang telah dikemas dengan kemasan primer.

c) Kemasar tersier dan kuartener yaitu kemasan untuk mengemas setelah kemasan primer atau sekunder.

3. Klasifikasi kemasan berdasarkan sifat kekauan bahan kemasan :

a) Kemasan fleksibel yaitu bahan kemasan yang mudah dilenturkan tanpa adanya retak atau patah. Misalnya plastik, kertas dan foil.

b) Kemasan kaku yaitu bahan kemas yang bersifat keras, kaku, tidak tahan lenturan, patah bila dibengkokkan relatif lebih tebal dari kemasan fleksibel. Misalnya kayu, gelas dan logam.

c) Kemasan semi kaku/semi fleksibel yaitu bahan kemas yan memiliki sifat-sifat antara kemasan fleksibel dan kemasan kaku. Misalnya botol plastik (susu, kecap, saus), dan wadah bahan yang berbentuk pasta.

4. Klasifikasi kemasan berdasarkan sifat perlindungan terhadap lingkungan:

a) Kemasan hermetis (tahan uap dan gas) yaitu kemasan yang secara sempurna tidak dapat dilalui oleh gas, udara atau uap air sehingga selama masih hermetis wadah ini tidak dapat dilalui oleh bakteri, kapang, ragi dan debu. Misalnya kaleng, botol gelas yang ditutup secara hermetis.

b) Kemasan tahan cahaya yaitu wadah yang tidak bersifat transparan, misalnya kemasan logam, kertas dan foil. Kemasan ini cocok untuk bahan pangan yang mengandung lemak dan vitamin yang tinggi, serta makanan hasil fermentasi.

c) Kemasan tahan suhu tinggi, yaitu kemasan untuk bahan yang memerlukan proses pemanasan, pasteurisasi dan sterilisasi. Umumnya terbuat dari logam dan gelas.

Berdasarkan klasifikasinya, secara umum kemasan memiliki peranan sebagai berikut:

1. Mempertahankan bahan dalam keadaan bersih dan higienis.

2. Mengurangi terbuangnya bahan selama distribusi.

3. Mempertahankan gizi produk yang dikemas.

4. Sebagai alat penakar, media informasi dan sekaligus sebagai sarana promosi.

Peranan ini dapat diperjelas dengan berperannya suatu kemasan dalam melindungi bahan pangan dari kerusakan 
dan penguraian serta dapat mempermudahpengangkutan transportasi

Hermawan Kartajaya, seorang pakar di bidang pemasaran mengatakan bahwa teknologi telah membuat kemasan menjadi berubah peran, dahulu orang mengatakan "Packaging protects what it sells" (Kemasan melindungi apa yang dijual). Pada saat ini, "Packaging sells what it protects" (Kemasan menjual apa yang dilindungi). Dengan kata lain, kemasan bukan lagi sebagai pelindung atau wadah tetapi harus dapat menjual produk yang dikemasnya. Perkembangan peran kemasan tidak hanya berhenti sampai di situ saja. Sekarang ini kemasan sudah berperan sebagai media komunikasi.

Kemasan juga dapat berperan untuk mengkomunikasikan suatu citra tertentu. Semua produk yang dijual di pasar harus benar-benar direncanakan kemasannya dengan baik. Karena produk dalam kategori yang sama akan diletakkan pada rak yang sama. Jika produsen ingin meluncurkan suatu produk baru, salah satu tugas yang penting adalah membuat kemasannya stands out, lain daripada yang lain dan unik. Jika tidak memberikan kesan berbeda dengan produk lain, maka produk baru tersebut akan "tenggelam". Sebelum mencoba isinya, konsumen akan menangkap kesan yang dikomunikasikan oleh kemasan. Dengan demikian kemasan produk baru tersebut harus mampu bersaing dengan kemasan produk-produk lainnya. Dengan melihat peran kemasan yang sangat penting, maka konsep peran pengemasan harus mencakup seluruh proses pemasaran dari konsepsi produk sampai ke pemakai akhir.
Secara umum tujuan desain kemasan adalah:

1. Menampilkan atribut unik sebuah produk untuk menjadi pembeda dengan produk lain, hal ini sebagia upaya untuk menarik perhatian.

2. Memperkuat penampilan estetika dan nilai produk.

3. Mempertahankan keseragaman dalam kesatuan merek produk.

4. Memperkuat perbedaan antara ragam produk dan lini produk.

5. Mengembangkan bentuk kemasan berbeda sesuai dengan kategori.

6. Menggunakan material baru dan mengembangkan struktur inovatif untuk mengurangi biaya, lebih ramah lingkungan, atau meningkatkan fungsionalitas. (Klimchuk, 2007: 49)

Pada dekade 1970-an ditandai dengan munculnya pasar swalayan, terjadi perubahan cara menjual produk-produk Indonesia khususnya produk makanan olahan, yaitu peran kemasan yang mulanya hanya sekedar wadah kemudian menjadi sebuah alat penjual. Selain itu juga gaya konsumen berpikir dalam hal belanja. Perubahan gaya hidup dan tekanan persaingan memberikan bobot yang besar akan pentingnya tampilan, daya tarik dan kualitas dari kemasan. Tuntutan akan desain yang berkualitas tinggi meningkat, dan juga cara berpromosi yang mengkaitkan antara grafika dan periklanan.

Perilaku konsumen dan pola belanja memiliki dampak yang sangat signifikan pada konsumsi terhadap makanan dan pembelian barang. Pada produk makanan, aspek kesehatan merupakan hal yang 
penting, pada produk non makanan hal yang terpenting adalah penjelasan mengenai fungsi dan spesifikasi. Perubahan sosial menimbulkan pemintaan akan berbagai macam jenis kemasan yang fleksibel dan berlainan (unik).

Pengemasan, disamping bertujuan untuk melindungi makanan tradisional dari kerusakan, juga merupakan daya pikat bagi orang agar terbujuk dan tertarik untuk membelinya. Keberhasilan daya tarik kemasan ditentukan oleh estetika yang menjadi bahan pertimbangan sejak awal perencanaan bentuk kemasan karena pada dasarnya nilai estetika harus terkandung dalam keserasian antara bentuk dan penataan desain grafis tanpa melupakan kesan jenis, ciri, dan sifat barang/produk yang diproduksi.

Pada pertengahan tahun 2007 Program Peningkatan Pendapatan Petani Melalui Inovasi (P4MI) melalui kegiatannya dilakukan upaya perbaikan pengemasan makanan siap saji guna meningkatkan daya pikat dan memenuhi persyaratan. Upaya perbaikan kemasan dilakukan melalui pendekatan studi orientasi, evaluasi teknologi dan pengembangan pengemasan. Jalur ini diharapkan mampu mendongkrak keberhasilan perdagangan makanan tradisional di daerah sentra produksi. Keberhasilan pemasaran makanan tradisional, disamping ditentukan oleh mutu dan keamanan makanan tradisional, juga usaha promosi yang harus diiringi dengan upaya dalam perbaikan tampilan kemasan. Hal ini serupa dengan budaya dasar dalam pemasaran yang sudah lazim di Inggris pada abad ke 19, "The Product is The Package", barang/produk ditentukan oleh kemasannya sendiri. Tidak kalah pentingnya dalam kemasan bahan makanan tradisional adalah adanya label. Karena label menjadi media informasi sebagai bahan pertimbangan untuk membeli/mengonsumsi pangan tersebut. Pada label berisi informasi mengenai gizi, jumlah gizi yang ada dan komposisi lainnya,mengandung penyebab alergi, masa kadaluwarsa, cara menyimpan, cara memasak, dan informasi penting lainnya yang dapat digunakan sebagai pedoman kita dalam membeli suatu produk.

\section{KEMASAN TRADISIONAL}

Yang dimaksud dengan kemasan tradisional adalah kemasan yang terbuat dari bahan alami umumnya digunakan untuk makanan tradisional, dan biasa digunakan sejak di pasar tradisional dengan menggunakan bahan-bahan alam. Penggunaan bahan-bahan alam pada perkemasan tradisional, memiliki unsurunsur khusus yang tidak terdapat pada unsur perkemasan modern yang menggunakan bahan-bahan buatan. Menurut Harundiah (1976) Unsur-unsur tersebut meliputi:

1. Penampilan

2. Aroma

3. Konstruksi

4. Hubungan dengan alam atau siklus alamiah

Penampilan pada kemasan tradisional terlihat lebih alami mulai dari warna, tekstur, dan bentuknya. Aroma dari kemasan tradisional memberikan cita rasa dan bau yang khas yang ditimbulkan dari sifat alamiah bahan alam yang dapat mempengaruhi produk di dalamnya. 
Konstruksi kemasan tradisional yang menggunakan bahan-bahan alam mempunyai kekuatan dan elastisitas tersendiri, yang tidak dapat dijumpai di bahan-bahan buatan pada kemasan modern.

Pada teknologi kemasan secara umum ada tuntutan kebutuhan, baik kebutuhan produsen maupun konsumen seperti yang dituliskan pada Indonesian Packaging Directory 2004-2005:

1. Material global dan tren pengemasan

2. Pasar mikro kemasan sesuai pesanan dan isi dengan karakter

3. Lingkungan pintar (RFID : Radio Frequency Identification and Swa Diagnostic. Yaitu semacam diagnose informasi keberadaan kualitas produk)

4. Lingkar pakai ulang dan lingkar nilai tambah

5. Etika baru ekoefektif dan penyederhanaan yang baru

6. Fleksimus untuk bepergian dan sekali pakai (kepentingan konsumen)

7. Pasar kelas atas dan bawah/murah (kepentingan produsen)

Banyak sekali produsen produk makanan dan non makanan di Indonesia khususnya UKM belum mempertimbangkan aspek-aspek tersebut diatas.

Kemasan tradisional antara lain berupa: Daun-daunan (seperti daun pisang, daun jagung, daun kelapa/enau (aren), daun jambu air dan daun jati). Ada juga kemasan dari anyaman bambu dan rotan dalam bentuk silindris maupun kotak seperti besek, keranjang buah dan sebagainya. Selain itu ada juga kemasan dari kulit atau kelobot jagung, yang juga memiliki keunikan tersendiri. Namun semakin hari, kemasan-kemasan tersebut semakin jarang dijumpai. Kedudukan besek mulai tergantikan oleh kotak kardus, plastik dan styrofoam. Dahulu bahan baku alam mudah ditemukan, jadi banyak yang membuat kemasan menggunakan bahan dari alam. Hal ini berlangsung terusmenerus hingga tahun 60-an. Pada era orde baru, lahir industri sintetis. Keberadaan bungkus tradisional perlahan-lahan mulai digantikan oleh kehadiran plastik, kresek, sampai Styrofoam. Hal tersebut merupakan alasan kenapa kemasan tradisional mulai jarang digunakan. Antara lain, karena selera dan perilaku masyarakat mulai berpihak pada kemasan instan yang lebih praktis dan tahan lama. Selebihnya karena faktor biaya, keterbatasan bahan baku dan mulai berkurangnya tenaga kerja yang terlatih untuk membungkus kemasan tradisional terutama besek.

Di daerah-daerah tertentu yang ada di Indonesia, terdapat banyak jajanan khas daerah setempat yang dibungkus dengan kemasan plastik, kertas, dll. Sebagai contoh misalnya wingko babat, bakpia pathuk, enting-enting, getuk, krupuk karak, rengginang, brem, kripik balado, dll. Hal ini sebenarnya tidak ada kesalahan pada "desain" terhadap kemasan jajanan tradisional ini. Namun seiring dengan tuntutan zaman dan komoditas pasar, kolaborasi desainer dan UKM setempat diharapkan mampu memberikan nilai tambah, agar dapat mewujudkan peningkatan usaha kecil dan menengah, peningkatan ekspor, pembentukan hubungan industri, dan peningkatan industri khas daerah untuk disalurkan ke pasar dunia. Selama ini, kemasan 
tradisional masih dikerjakan oleh UKM atau industri kecil dan menengah. Pembuatan kemasan hanya berdasarkan pada desain yang turun-temurun dan seadanya, sehingga dampaknya terhadap produk makanan tradisional jadi terlihat kampungan dan lemah dalam menyampaikan komunikasi dan informasi melalui desain. Jika rata-rata jajanan tersebut hanya dimasukkan ke dalam plastik lalu diberi cap atau dimasukkan ke dalam boks lalu diberi label kecil, kadang hanya berupa label yang di foto kopi. Hal ini menunjukkan kurangnya informasi tentang desain di kalangan pengrajin/UKM, menjadikan beberapa kemasan jajanan tradisional terlihat kampungan dan lemah dalam persaingan, baik lokal apalagi internasional.

Tren kemasan tradisional kini terus menjamur. Melihat fenomena ini, beberapa pengusaha makanan tradisional memanfaatkannya untuk menarik perhatian dan mendongkrak penjualan produknya. Kemasan tradisional dengan motif khas kedaerahan sebenarnya sudah lama dimanfaatkan, hanya seiring perkembangan jaman sempat meredup, namun mulai tahun 2007 kembali naik daun.

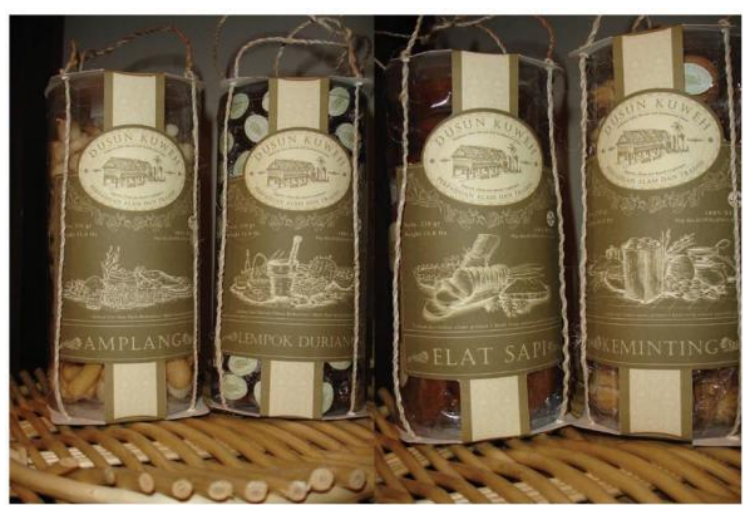

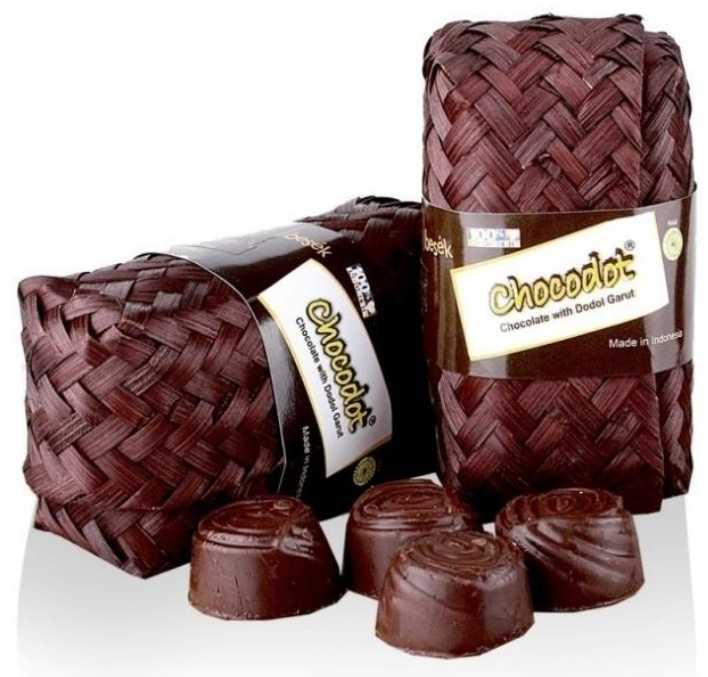

Gambar 2. Contoh kemasan tradisional yang mencirikan daerah tertentu.

Selama ini kemasan modern dengan beragam material sudah banyak beredar, sedangkan untuk mengembalikan image makanan tradisional, perajin mulai kembali mencari bahan - bahan tradisional untuk mengemasnya. Kemasan tradisional pada umumnya menggunakan material bahan langsung dari alam seperti daun, bambu, kayu, rotan, serat dan sebagainya. Namun dalam hal ini kemasan tradisional juga dapat disiasati dengan menggunakan bahan kertas. Bahan kertas merupakan alternatif pilihan terbaik terhadap ramah lingkungan dan dapat didaur ulang. Tidak menutup kemungkinan kertas juga dapat digunakan untuk menyerupai tampilan dengan yang berbahan alam, yaitu dengan membuat struktur serta motifnya yang menyerupai motif alam seperti bentuk anyaman bambu, bentuk serat kayu, serat kulit jagung dan sebagainya. Dengan tampilan desain kemasan yang menarik, akan mempengaruhi naiknya nilai jual. Hal ini tentunya mampu mendongkrak penjualan produknya. Penjualan produk dengan kemasan bermotif tradisional 
inipun cukup tinggi meski sedikit lebih mahal dibanding kemasan konvensional. Namun demikian justru hal ini menjadi pilihan utama bagi pengusaha oleh-oleh dalam hal pengemasan karena ditinjau dari sisi keunikannya.

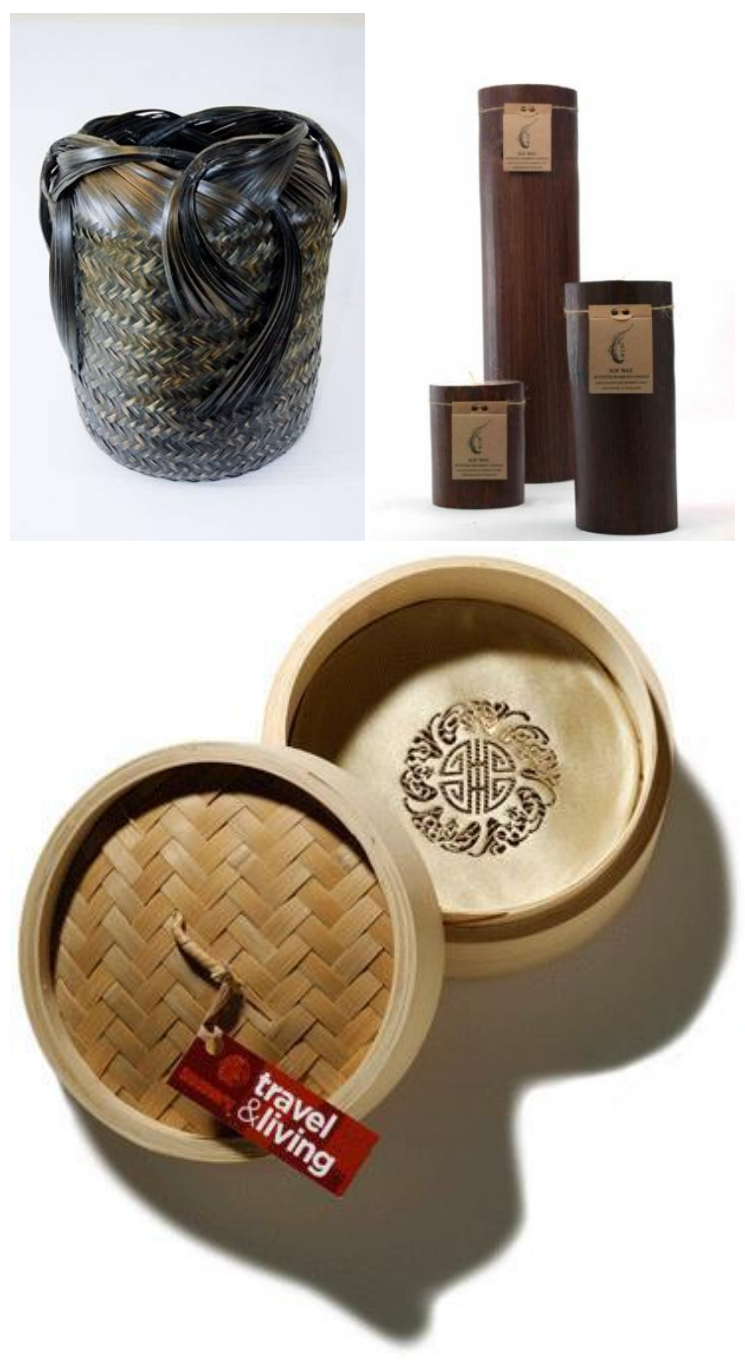

Gambar 2. Contoh kemasan tradisional yang mencirikan daerah tertentu.

Kemasan tradisional yang baik memiliki desain yang unik, modis dan trendi tanpa mengabaikan tujuan fungsional kemasan. Dalam hal ini menunjukkan peran para desainer yang utama, yaitu kreativitas dalam mendesain ulang kemasan-kemasan tradisional dengan tanpa mengabaikan identitas lokal dan jati dirinya yang unik dan mampu mewakili budaya lokal. Dengan demikian ketertarikan konsumen akan membeli makanan tradisional bukan hanya karena isinya, tapi juga karena daya tarik kemasannya yang unik. Desain yang selalu inovatif dapat memunculkan keinginan pembeli untuk mengoleksinya.

\section{KESIMPULAN}

Seiring dengan perkembangan teknologi dan gaya hidup, kemasan tradisional untuk makanan alami kini mulai ditinggalkan masyarakat karena dinilai menjadi kemasan yang terkesan murahan dan diidentikan dengan kumuh, tidak higienis, tidak praktis. Kemudian perlahan berganti dengan pembungkus/wadah buatan manusia yang kini biasa kita gunakan seperti kertas, plastik, kaleng dan Styrofoam. Selama ini, wadah dan pembungkus modern memang menciptakan kesan modern, praktis, simple dan bersih. Namun permasalahannya, material seperti ini sulit didaur ulang, menimbulkan limbah yang berlapis-lapis, sehingga rentan mencemari lingkungan.

Seiring dengan munculnya berbagai permasalahan yang terjadi, maka perlu adanya solusi untuk mempertahankan dan menciptakan kemasan tradisional yang lebih layak digunakan, yaitu kemasan tradisional yang tetap menggunakan bahan alami namun tidak tampil apa adanya. Kemasan tradisional harus tampil unik dan memiliki kekuatan dalam menampilkan identitas kedaerahannya sebagai penghasil makanan tradisional tersebut. 
Keberhasilan pemasaran makanan tradisional, disamping ditentukan oleh mutu dan keamanan makanan tradisional, juga usaha promosi yang harus dibarengi dengan upaya dalam perbaikan tampilan kemasan yang fleksibel dan berlainan (unik) agar memiliki daya tarik tersendiri. Keberhasilan daya tarik kemasan ditentukan oleh estetika yang menjadi bahan pertimbangan sejak awal perencanaan bentuk kemasan karena pada dasarnya nilai estetika harus terkandung dalam keserasian antara bentuk dan penataan desain grafis tanpa melupakan kesan jenis, ciri, dan sifat barang/produk yang diproduksi. Sehingga untuk makanan khas tentunya kemasan tersebut mampu untuk mencirikan suatu daerah tertentu. Perlu adanya kolaborasi antara desainer dan UKM, pentingnya kerjasama tersebut diharapkan mampu memberikan nilai tambah agar dapat mewujudkan peningkatan usaha kecil dan menengah, peningkatan ekspor, pembentukan hubungan industri, dan peningkatan industri khas daerah untuk disalurkan ke pasar dunia.

Kemasan tradisional selain menggunakan material alam, bahan kertaspun merupakan alternatif terbaik terhadap ramah lingkungan dan dapat didaur ulang. Tidak menutup kemungkinan kertas juga dapat digunakan untuk menampilan kesan alami, yaitu dengan membuat struktur serta motifnya yang menyerupai motif alam seperti bentuk anyaman bambu, bentuk serat kayu, serat kulit jagung dan sebagainya.

Bagaimanapun juga kekhasan kemasan tradisional belum mampu tergantikan. Kemasan tradisional cenderung memiliki banyak kelebihan. Kemasan tradisional perlu memperhatikan beberapa aspek yang disesuaikan dengan kondisi saat ini. Sebagai desainer, sudah sepatutnya kita mengambil tanggung-jawab untuk mempertahankan keberadaan kemasan tradisional, bahkan memperjuangkannya untuk lebih eksis dan makin dihargai, sehingga kemasan tradisional sebagai bungkus makanan tradisional yang dari sisi estetis menarik dan fungsional, tidak lagi dianggap sebagai kemasan yang terkesan murahan, kumuh, dan selalu menghadirkan bentuk yang selalu sama dari masa ke masa. Peran desainer adalah menciptakan kemasan tradisional dalam konteks kekinian, yaitu lebih dinamis ditinjau dari beberapa aspek dalam kondisi saat ini, antara lain dari sisi desain yang lebih inovatif sehingga memiliki keunikan dan nilai jual tinggi mengingat semakin banyaknya produk yang ada di pasaran. Adanya sentuhan desain yang unik akan mampu membuat kemasan tradisional menjadi sebuah kemasan yang eksklusif. Kemasan tradisional juga diciptakan supaya mampu mempertahankan ciri khas kebudayaan setempat tanpa mengabaikan identitas lokal untuk mewakili budaya lokal. Pertimbangan yang lebih penting juga perlu memperhatikan dari sisi ramah lingkungan, mengingat kini masalah sampah mulai marak disuarakan, jadi kemasan tradisional harus mudah untuk didaur ulang. 


\section{DAFTAR PUSTAKA}

1. Wibowo, Tri. 2002. Teori warna untuk de

2. Agustina, W. 2009. Desain Kemasan dan Label Produk Makanan. Kumpulan Modul pelatihan. UPT B2PTTG-LIPI Subang.

3. Cenadi, Christine Suharto. 2000. Peranan Desain Kemasan dalam Dunia Pemasaran. Jurnal Vol. 2, No. 1, Januari 2000: 92 - 103.

4. F.G. Winarno, ed. 1999. Kumpulan Makanan Tradisional I, Pusat Kajian Makanan Tradisional Perguruan Tinggi Departemen Pendidikan dan Kebudayaan, Jakarta.

5. Herudiyanto, Marleen S. 2008. Teknologi Pengemasan Pangan. Bandung: Widya Padjadjaran.

6. Indonesian Packaging Directory2004-2005, Federasi Pengemasan Indonesia, 2005. Jakarta.

7. Julianti, E. dan Nurminah, M. 2006. Teknologi Pengemasan. Departemen Teknologi Pertanian, Fakultas pertanian, Universitas Sumatera.

8. Rosner, Klimchuk Marianne dan Sandra A. Krasovec. 2002. Desain Kemasan. Jakarta: Erlangga.

9. Sabana, Setiawan. 2007. Nilai Estetis Pada Kemasan Makanan Tradisional Yogyakarta. Jurnal Vis. Art. Vol. 1 D, No. 1, 10-25. ITB Bandung. 